\title{
Dysglycemia and Dyslipidemia Models in Nonhuman Primates: Part IV. Pancreatic Beta Cell Dysfunction and Diabetes Progression
}

\author{
Yong-Fu Xiao*, Yixin (Jim) Wang \\ Cardiovascular and Metabolic Diseases, Crown Bioscience Inc., Taicang, Jiangsu Province, The People's Republic of China
}

\begin{abstract}
Diabetes mellitus, hyperglycemia and polyuria, results from the body either producing insufficient insulin or using the produced insulin inefficiently to metabolize glucose. Type I diabetes mellitus (T1DM) is recognized as reduction of beta-cell mass mostly due to autoimmune destruction. However, insulin resistance and beta-cell dysfunction or loss are potentially the main causes of Type II diabetes mellitus (T2DM). Due to long-term hyperglycemia and microvascular impairment, complications are common, including heart, kidney, liver and other organs. Therefore, diabetic patients have the overall high risk of dying prematurely by heart attack, stroke, liver dysfunction and kidney failure. Diabetes has become one of the major global threats to human health. Development of safe and potent therapeutics is thus urgently needed. Animal models remain irreplaceable for discovering, validating and optimizing novel therapeutics for their safe use in clinics. Selection of appropriate animal models is critical for obtaining crucial data to translate preclinical research to clinical trial. It has been recognized that the pancreas structure and pathophysiology in rodents greatly differ from those in humans, but in nonhuman primates (NHPs) are more similar to humans. Many researchers have used spontaneously developed or drug-induced diabetic NHPs as the models to investigate diabetes progression and novel therapies. This article summarized some characteristics of the disease progression in a large pool of diabetic NHPs.
\end{abstract}

Keywords: Diabetes; Nonhuman primate; Beta cell; Diabetes progression

Abbreviations: AAALAC: Association for Assessment and Accreditation of Laboratory Animal Care; ALT: Alanine Aminotransferase; AST:AspartateAminotransferase; AUC: Area Under the Curve; EDTA: Ethylenediaminetetraacetic Acid; FI: Food Intake; GLUT2: Glucose Transporter 2; HbA1c: Hemoglobin A1c; HDL: High Density Lipoprotein; IACUC: Institutional Animal Care and Use Committee; ivGTT: Intravenous Glucose Tolerance Test; LDL: Low Density Lipoprotein; NHPs: Non-Human Primates; oGTT: Oral Glucose Tolerance Test; proBNP: Pro B-type Natriuretic Peptide; SEM: Standard Error of the Mean; STZ: Streptozocin; TC: Total Cholesterol; TG: Triglycerides; T1DM: Type I Diabetes Mellitus; T2DM: Type II Diabetes Mellitus

\section{INTRODUCTION}

Obesity has become a worldwide epidemic issue and can lead to diabetes because of insulin resistance. Several hypotheses for insulin resistance have been postulated and documented. Among those are inflammation, mitochondrial dysfunction, hyperinsulinemia and lipotoxicity $[1,2]$. Others, such as genetic background, aging, fatty liver, endoplasmic reticulum stress, hypoxia and lipodystrophy are the areas under active research for understanding mechanisms of insulin resistance [1]. Pancreatic beta-cell dysfunction and loss are the key pathophysiological factors in development of diabetes mellitus (type 1 and type 2). Due to relatively insulin deficiency and unable to properly metabolize glucose, diabetic patients manifest hyperglycemia and polyuria. The world prevalence of diabetes among adults (aged 20-79 years) are predicted to be 439 million by 2030 [3], which becomes a major threat to human health. If without proper treatment, diabetic patients can eventually develop diabetic complications of the kidneys, liver, heart and other organs, which may significantly impact on their quality of life.

Potential new therapies and technologies will help to improve the quality of life beyond current standard of care and perhaps even to cure the disease in future [4,5]. Various animal models have been used in preclinical research for understanding the disease and discovering new novel therapies [6-9]. NHPs can naturally develop T2DM [10-15]. Therefore, diabetes in NHPs represents

Correspondence to: Yong-Fu Xiao, MD, PhD, Cardiovascular and Metabolic Diseases, Crown Bioscience, Inc., 6 Beijing West Road, Taicang, Jiangsu Province, The People's Republic of China 215400, Tel: +86-512-5387-9826; Fax: +86-512-5387-9981; E-mail: xiaoyongfu@crownbio.com

Received: August 16, 2019, Accepted: September 03, 2019, Published: September 10, 2019

Citation: Xiao YF, Wang YJ (2019) Dysglycemia and Dyslipidemia Models in Nonhuman Primates: Part IV. Pancreatic Beta Cell Dysfunction and Diabetes Progression. J Diabetes Metab. 10:832. doi: 10.35248/2155-6156.19.10.832

Copyright: (c) 2019 Xiao YF, et al. This is an open-access article distributed under the terms of the Creative Commons Attribution License, which permits unrestricted use, distribution, and reproduction in any medium, provided the original author and source are credited. 
a crucial pre-clinical model with important similarity to human endocrine physiology that facilitates translation of experimental findings to clinic. Diabetes accelerates the atherosclerotic process and its morbid consequences. Nutraceuticals and functional food ingredients may potentially reduce the overall cardiovascular risk from dyslipidemia [16]. Compared with humans, NHPs are more accessible and feasible for biopsy and tissue/organ collection for histopathology. NHP models are also used for investigation of diabetic complications and discovery of new mechanism and therapeutic strategy or target $[17,18]$.

Though diabetes can be treated with oral antidiabetic drugs or subcutaneous insulin injection, these treatments do not provide the same degree of glycemic control as functional pancreatic $\beta$-cells and do not prevent the debilitating consequences of the disease. Treatments that replenish $\beta$-cell mass in diabetic patients could allow for the long-term restoration of normal glycemic control and thus represent a potentially curative therapy. It has been known that the pancreas pathophysiology in rodents differed from that in humans greatly, but in NHPs was more close to in humans [19-21]. Streptozocin (STZ)-induced diabetes in NHPs is also used to investigate diabetes progression and therapy [22-26], because naturally developed diabetes may take years to show the phenotype and raise the difficulty to monitor the disease progress. STZ-induced diabetes can be predicted in a short period of time. Due to limited availability of spontaneously diabetic NHPs and other specific reasons, drug-induced diabetes in NHPs is also highly valuable for scientific research on diabetic etiology and its complications. STZinduced diabetes can give us the relative convenience of monitoring the dynamic changes from non-diabetes to diabetes in a designated duration. In addition, islet transplantation is an attractive treatment for diabetes, especially for Type I. Therefore, STZ-induced diabetes in NHPs is one of suitable models for evaluating the effectiveness of islet transplantation [15,27].

This article summarizes some characteristics of naturally occurring or drug-induced diabetes in a large pool of NHPs. Normal and obese/diabetic monkeys housed in our animal center are collected periodically from the monkey farms in China and then raised in our own facility [28-30]. Monkeys raised in indoor cages with food ad libitum increase the chance to become obesity which facilitates development of obesity-associated diseases in an age-dependent manner [31-34]. Like humans, these monkeys can develop to Type 2 diabetes mellitus and other complications, such as nephropathy, orthmopathy, neuropathy, liver and cardiovascular complications $[12,31,35]$.

\section{SPONTANEOUSLY DEVELOPED DIABETES IN NHPS}

Experiments were performed in normoglycemic and hyperglycemic cynomolgus monkeys of either sex (Table 1). The diabetic monkeys were selected from spontaneously developed diabetic ones who met the diabetes criteria and were housed in our animal facility [10]. These monkeys were individually housed and maintained in our animal facility in accordance with the guidelines of the Association for Assessment and Accreditation of Laboratory Animal Care (AAALAC). The room temperature was maintained at $\sim 21^{\circ} \mathrm{C}$ with a 12 hrs light/dark cycle with lights on from 7 AM to 7 PM. All the animals were free access ad libitum to water and a complete, nutritionally balanced normal diet (Beijing Keao Xieli Feed Co., LTD, Beijing, China) enriched with seasonal fruit and vegetables. The experimental protocol was approved by the Institutional Animal Care and Use Committee (IACUC) of Crown Bioscience, Inc.

To obtain the parameters showed in Tables and Figures in this manuscript, each overnight-fasted (approximately $16 \mathrm{hrs)} \mathrm{monkey}$ sit in a monkey chair. The body weight was measured and recorded. Blood (2 mL/each) was collected from a cephalic or saphenous vein into BD Vacutainer ${ }^{\circledR}$ SST II Plus plastic serum tubes. The animal was then returned to its cage after blood collection. The sample tube was left at room temperature (approximately $21^{\circ} \mathrm{C}$ ) for $30 \mathrm{~min}$. Serum was separated by centrifugation at $3000 \mathrm{rpm}$ for $15 \mathrm{~min}$ at $4^{\circ} \mathrm{C}$. Another blood sample was kept at $4^{\circ} \mathrm{C}$ for glycated hemoglobin (Hb1Ac) assay. All the samples were analyzed within 3 to 4 hrs after blood collection. Blood HbA1c (by ionexchange HPLC), serum lipids, glucose (by Siemens Advia-2400) and insulin (by Siemens Advia Centaur XP) were analyzed at the

Table 1: General characteristics of the normoglycemia and hyperglycemia NHPs.

\begin{tabular}{|c|c|c|c|}
\hline \multirow{2}{*}{ Parameter } & Normoglycemia & Hyperglycemia & \multirow{2}{*}{$p$ value } \\
\hline & $(\mathrm{M} \pm \mathrm{SE}(\mathrm{n}, \mathrm{F} / \mathrm{M}))$ & $(\mathrm{M} \pm \mathrm{SE}(\mathrm{n}, \mathrm{F} / \mathrm{M}))$ & \\
\hline Age (year) & $13.5 \pm 0.2(342,9 / 333)$ & $15.8 \pm 0.2(801,179 / 622)$ & $<0.0001^{* * * *}$ \\
\hline Body weight $(\mathrm{kg})$ & $9.4 \pm 0.1(342,9 / 333)$ & $8.9 \pm 0.1(801,179 / 622)$ & $0.0009^{* * *}$ \\
\hline Glucose $(\mathrm{mg} / \mathrm{dL})$ & $69.8 \pm 0.5(342,9 / 333)$ & $190.2 \pm 3.6(704,141 / 563)$ & $<0.0001^{* * * *}$ \\
\hline Insulin (mIU/L) & $104.8 \pm 9.7(236,7 / 229)$ & $101.0 \pm 9.1(561,112 / 449)$ & 0.7772 \\
\hline C-peptide (nmol/L) & $1.5 \pm 0.1(82,1 / 81)$ & $1.5 \pm 0.1(190,37 / 153)$ & 0.9649 \\
\hline HbA1c (\%) & $4.8 \pm 0.1(173,5 / 168)$ & $8.7 \pm 0.1(525,95 / 430)$ & $<0.0001^{* * * *}$ \\
\hline $\mathrm{TG}(\mathrm{mg} / \mathrm{dL})$ & $100.3 \pm 9.8(267,7 / 260)$ & $243.8 \pm 11.4(610,106 / 504)$ & $<0.0001^{* * * *}$ \\
\hline $\mathrm{TC}(\mathrm{mg} / \mathrm{dL})$ & $134.2 \pm 9.6(265,7 / 258)$ & $155.6 \pm 5.2(612,106 / 506)$ & $0.0052^{* *}$ \\
\hline $\mathrm{HDL}(\mathrm{mg} / \mathrm{dL})$ & $62.5 \pm 2.1(252,7 / 250)$ & $45.4 \pm 1.1(516,79 / 437)$ & $<0.0001^{* * * *}$ \\
\hline $\mathrm{LDL}(\mathrm{mg} / \mathrm{dL})$ & $67.5 \pm 5.3(254,7 / 247)$ & $77.8 \pm 4.4(520,79 / 441)$ & 0.1333 \\
\hline Leptin (ng/mL) & $24.8 \pm 0.7(11,1 / 10)$ & $23.4 \pm 0.9(12,6 / 6)$ & 0.237 \\
\hline proBNP $(\mathrm{ng} / \mathrm{mL})$ & $11.8 \pm 1.4(8,0 / 8)$ & $9.5 \pm 1.1(24,12 / 12)$ & 0.209 \\
\hline ivGTT AUC $\left(\mathrm{mg} / \mathrm{dL}^{*} \mathrm{~min}\right)$ & $4523 \pm 563(8,0 / 8)$ & $7274 \pm 415(24,12 / 12)$ & $0.0012^{* *}$ \\
\hline oGTT AUC (mg/dL*min) & $20626 \pm 3349(8,0 / 8)$ & $44086 \pm 2552(90,10 / 80)$ & $<0.0001^{* * * *}$ \\
\hline
\end{tabular}

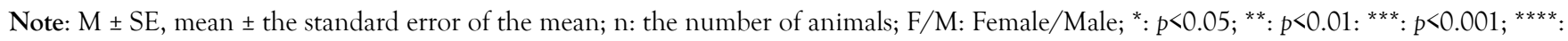
$p<0.0001$; versus Normoglycemia. 
clinical laboratory (The First People's Hospital of Taicang, Taicang, Jiangsu Province, China). Serum leptin and pro-BNP (pro b-type natriuretic peptide) were measured with immunoassay (ELISA Kits, MyBioSource, San Diego, California, USA) specifically targeting the monkey.

Intravenous glucose tolerance test (ivGTT) was conducted in our study to evaluate the metabolic stages of the monkeys [36,37]. The monkeys were objectively divided into 2 distinct groups based on their serum glucose levels (Table 1$)$, normoglycemia $(<85 \mathrm{mg} / \mathrm{dL}$, $\mathrm{n}=8$ ) and hyperglycemia ( $\geq 85 \mathrm{mg} / \mathrm{dL}, \mathrm{n}=24)$. The animals were fasted for overnight $16 \mathrm{hrs}$ and anesthetized with an initial dose of ketamine at $10 \mathrm{mg} / \mathrm{kg}$ intramuscularly (i.m.) and then with 5 $\mathrm{mg} / \mathrm{kg}$ supplement if needed. The cephalic and/or saphenous veins were cannulated separately for glucose infusion and blood collection. Glucose $(0.25 \mathrm{~g} / \mathrm{kg}=0.5 \mathrm{~mL} / \mathrm{kg}$ of $50 \%$ dextrose $)$ was intravenously infused within a 30 second period and the system was flushed with $5 \mathrm{~mL}$ saline to remove residual glucose. Blood was collected immediately before and then at 3, 5, 7, 10, 15, 20, 30 min after glucose infusion. Collected blood samples were kept at room temperature $\left(21^{\circ} \mathrm{C}\right)$ for $30 \mathrm{~min}$ and then centrifuged at 3,500 rpm for $10 \mathrm{~min}$ to obtain the serum. Serum glucose and insulin were measured in the clinical laboratory (Taicang $1^{\text {st }}$ People's Hospital, Jiangsu, China).

For oral glucose tolerance test (oGTT), each monkey was overnight fasted for approximately $16 \mathrm{hrs}$. After being placed in a monkey chair, a nasal/oral gavage tube was placed into the stomach. Glucose $1.75 \mathrm{~g} / \mathrm{kg}$ in $35 \%$ glucose solution was administered via the gavage tube at $5 \mathrm{~mL} / \mathrm{kg}$ in each conscious animal followed by flashing with $5 \mathrm{~mL} 0.9 \%$ saline to wash the residual glucose solution into the stomach. Blood samples were collected and processed. Serum glucose and insulin levels were measured before and 15, 30, 60, 90, 120, $180 \mathrm{~min}$ after glucose administration. The animal was placed back to its cage from the monkey chair after completion of oGTT. Serum glucose and insulin were measured in the clinical laboratory (Taicang $1^{\text {st }}$ People's Hospital, Jiangsu, China).

\section{General characteristics of spontaneous diabetes in NHPs}

Some metabolic characteristics of the male and female monkeys being housed in our animal facility are shown in Figure 1. Clearly, compared to the male monkeys, the female ones were significantly older (Figure 1A, $p<0.001$ ) and showed significantly higher glucose and HbA1c levels (Figures 1C and 1D, $p<0.001$ ). The serum proBNP and leptin levels were very similar between female and male monkeys ( $p>0.05$; Figures $1 \mathrm{G}$ and $1 \mathrm{H})$. In contrast, the body weight $(p<0.001)$, insulin $(p<0.001)$ and C-peptide $(p<0.01)$ levels were significantly lower in the female monkeys than in the male ones (Figures 1B, 1E and 1F). The data indicate that compared with the male monkeys, our housed female ones were older and showed more late stage diabetes (Figure 1). Most of the monkeys enrolled in this study are currently alive and have been housed in our animal facility for diabetes and dyslipidemia research for many years.

Multiple reports clearly show that normal fasting serum glucose concentrations in monkeys are about $30 \mathrm{mg} / \mathrm{dL}$ lower than those in normal humans $[10,12,17]$. The monkeys housed in our facility with their fasting serum glucose $<85 \mathrm{mg} / \mathrm{dL}(69.8 \pm 0.5 \mathrm{mg} / \mathrm{dL}$, mean \pm SE, $n=342$, Table 1 ) were listed in the normoglycemic group. Those animals showed their fasting serum glucose levels equal or higher than $85 \mathrm{mg} / \mathrm{dL}$ were placed in the hyperglycemic group $(190.2 \pm 3.6 \mathrm{mg} / \mathrm{dL}, \mathrm{n}=704, p<0.05$, vs. Normoglycemia, Table 1). In the meantime, compared with normoglycemic animals, the hyperglycemic monkeys were significantly older with higher blood HbA1c, TG (triglycerides), TC (total cholesterol), ivGTT AUC (area under the curve), and oGTT AUC ( $p<0.05$ to 0.0001 , Table 1). In contrast, body weight and serum HDL (high density lipoprotein) level were significantly lower in the hyperglycemic group than in the normoglycemic group $(p<0.001$ to 0.0001 , Table 1). Interestingly, serum insulin, C-peptide, LDL (low density lipoprotein), leptin and pro-BNP levels were not significantly different between normoglycemic and hyperglycemic groups ( $p>0.05$, Table 1). Our data demonstrate that diabetic monkeys were much older than normoglycemic ones in our animal facility.
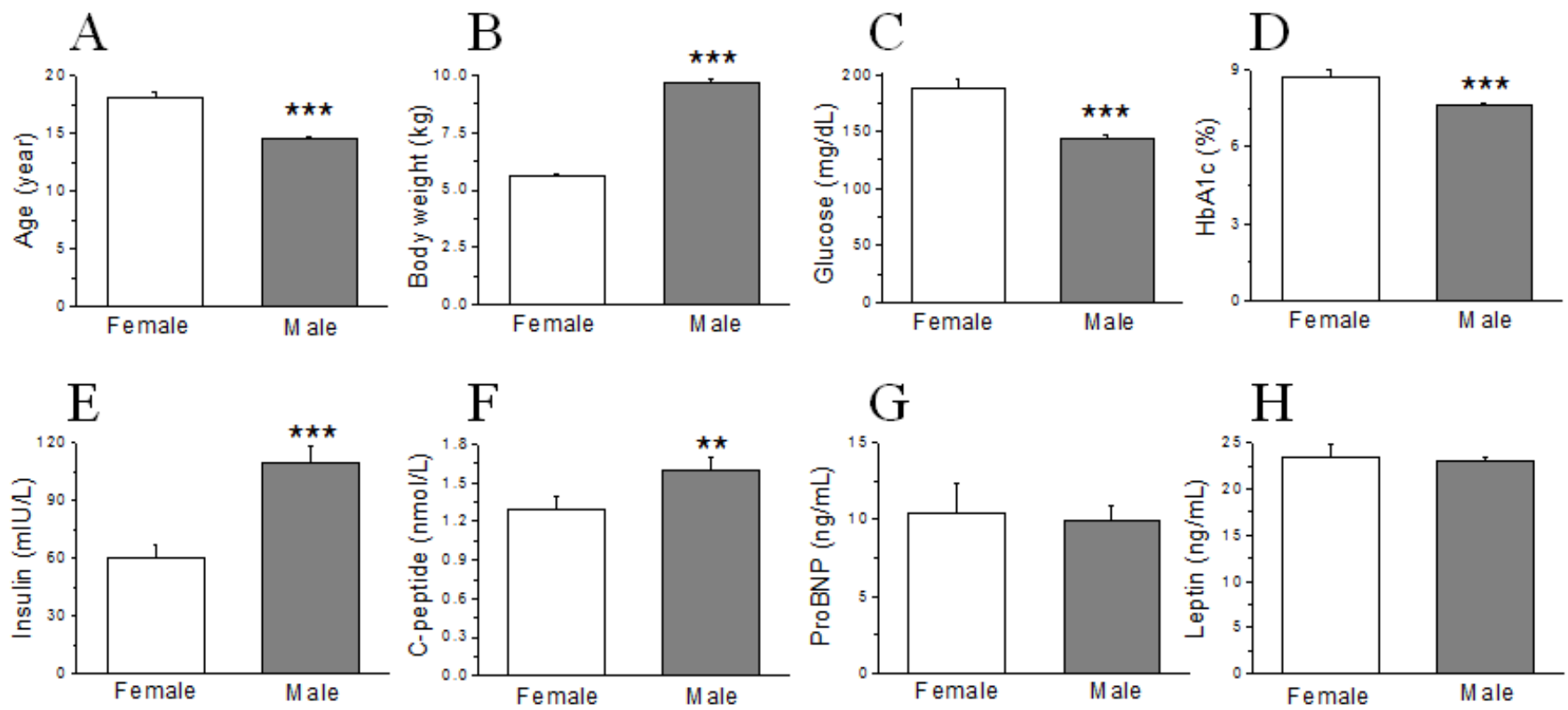

Figure 1: The differences of age $(\mathrm{F} / \mathrm{M}($ Female/Male)=172/971), body weight $(\mathrm{F} / \mathrm{M}=180 / 978)$, serum glucose (F/M=149/899), blood HbA1c (F/ $\mathrm{M}=97 / 601)$, serum insulin ( $\mathrm{F} / \mathrm{M}=119 / 678)$, C-peptide ( $\mathrm{F} / \mathrm{M}=53 / 219)$, porBNP $(\mathrm{F} / \mathrm{M}=11 / 21)$ and leptin $(\mathrm{F} / \mathrm{M}=8 / 34)$ between female and male monkeys. ${ }^{* *}, p<0.01 ;{ }^{* * *}, p<0.001 ;$ vs. Female. 
Compared with normoglycemic monkeys, diabetics ones showed significantly lower body weight with higher glucose, HbA1c, TG, TC, ivGTT AUC and oGTT AUC.

\section{Correlations among age, body weight and serum/urine parameters}

The ages of the experimental animals correlated significantly well with their serum glucose (Figure 2A, $p<0.001$ ) and blood HbA1c (Figure 2B, $p<0.0001$ ) levels. Their ages did not correlate well with their serum insulin levels (Figure 2D, $p>0.05$ ), but negatively correlated well with serum C-peptide levels (Figure 2C, $p<0.05$ ). Interestingly, the body weights, not like their ages (Figures $2 \mathrm{C}$ and 2D), of the animals showed significant correlation with serum C-peptide (Figure 2G, $p<0.001$ ) and insulin (Figure 2H, $p<0.0001$ ) levels. In addition, their body weights negatively correlated with serum glucose (Figure 2E, $p<0.001$ ) and blood HbA1c (Figure $2 \mathrm{~F}, p<0.001)$ levels. Our results indicate that when the animals got older, hyperglycemia and high HbA1C became more severe, but serum insulin and C-peptide levels were decreased because of dysfunction and/or loss of pancreatic beta-cell masses due to impairment of long time hyperglycemia. However, as obesity could cause insulin resistance with compensational more insulin secretion and as diabetic NHPs at their late stages might lose their body weights and pancreatic beta-cell masses, the insulin and C-peptide levels thus correlated positively with the body weights in the experimental NHPs (Figure 2). In addition, due to the similar reasons, the glucose and $\mathrm{HbA1c}$ levels positively correlated with the ages, but negatively correlated with body weights (Figure 2).

Blood glucose in the bloodstream is transported to all cells in the body as one of the energy sources. A healthy person needs to keep blood levels within a safe range to prevent the risk of diabetes and heart disease. Hyperglycemia is a major concern for those who suffer from type 1 or type 2 diabetes. In order to learn about the effects of blood glucose levels on other blood biomedical parameters and renal functions, the correlations between serum glucose levels and other blood and urine parameters were analyzed. The results of the correlations and statistical significances are shown in Table 2. Clearly, the serum glucose levels did not correlate well with the serum insulin levels, because some diabetic animals at their late stages had much high blood glucose accompanied with significantly low insulin. The potential explanation is long-term hyperglycemia in diabetic NHPs, especial at late stage, led to pancreatic beta-cell dysfunction and loss, which decreases the capability of the pancreas to synthesize and secret insulin.

Table 2: Correlations between serum glucose levels and other biochemical parameters.

\begin{tabular}{|c|c|c|}
\hline Correlation & $\mathrm{R}$ & $\mathrm{p}$ \\
\hline \multicolumn{3}{|l|}{ Serum glucose levels/other parameters } \\
\hline Glucose $(\mathrm{mg} / \mathrm{dL}) / \operatorname{Insulin}(\mathrm{mIU} / \mathrm{L})(\mathrm{n}=787)$ & -0.05 & $>0.05$ \\
\hline Glucose $(\mathrm{mg} / \mathrm{dL}) / C$-peptide $(\mathrm{nmol} / \mathrm{L})(\mathrm{n}=271)$ & -0.13 & $<0.05$ \\
\hline Glucose $(\mathrm{mg} / \mathrm{dL}) / \mathrm{HbA1c}(\%)(\mathrm{n}=690)$ & 0.72 & $<0.0001$ \\
\hline Glucose $(\mathrm{mg} / \mathrm{dL}) / \mathrm{TG}(\mathrm{mg} / \mathrm{dL})(\mathrm{n}=845)$ & 0.43 & $<0.0001$ \\
\hline Glucose $(\mathrm{mg} / \mathrm{dL}) / \mathrm{TC}(\mathrm{mg} / \mathrm{dL})(\mathrm{n}=845)$ & 0.146 & $<0.0001$ \\
\hline Glucose (mg/dL)/LDL (mg/dL) $(\mathrm{n}=751)$ & 0.09 & $<0.05$ \\
\hline Glucose $(\mathrm{mg} / \mathrm{dL}) / \mathrm{HDL}(\mathrm{mg} / \mathrm{dL})(\mathrm{n}=745)$ & -0.27 & $<0.0001$ \\
\hline Glucose $(\mathrm{mg} / \mathrm{dL}) / \operatorname{ALT}(\mathrm{U} / \mathrm{L})(\mathrm{n}=547)$ & 0.43 & $<0.0001$ \\
\hline Glucose $(\mathrm{mg} / \mathrm{dL}) / \mathrm{AST}(\mathrm{U} / \mathrm{L})(\mathrm{n}=488)$ & 0.18 & $<0.0001$ \\
\hline Glucose $(\mathrm{mg} / \mathrm{dL}) / \mathrm{FI}(\mathrm{g} / 24)(\mathrm{n}=321)$ & 0.2 & $<0.0001$ \\
\hline \multicolumn{3}{|l|}{ Serum glucose levels/Urine parameters } \\
\hline Glucose $(\mathrm{mg} / \mathrm{dL}) /$ Volume $(\mathrm{mL} / 24 \mathrm{hrs})(\mathrm{n}=94)$ & 0.25 & $<0.05$ \\
\hline Glucose $(\mathrm{mg} / \mathrm{dL}) /$ Glucose $(\mathrm{mg} / 24 \mathrm{hrs})(\mathrm{n}=79)$ & 0.41 & $<0.001$ \\
\hline Glucose (mg/dL)/Albumin (mg/24 hrs) (n=97) & 0.14 & $>0.05$ \\
\hline Glucose $(\mathrm{mg} / \mathrm{dL}) /$ Total proteins $(\mathrm{mg} / 24 \mathrm{hrs})(\mathrm{n}=98)$ & 0.13 & $>0.05$ \\
\hline Glucose $(\mathrm{mg} / \mathrm{dL}) /$ Creatinine $(\mathrm{mmol} / 24 \mathrm{hrs})(\mathrm{n}=91)$ & 0.09 & $>0.05$ \\
\hline Glucose $(\mathrm{mg} / \mathrm{dL}) /$ Albumin creatinine ratio $(\mathrm{n}=100)$ & 0.18 & $>0.05$ \\
\hline
\end{tabular}

Note: Data points of two corresponding parameters were fitted by linear regression with the equation $\mathrm{Y}=\mathrm{A}+\mathrm{B}^{*} \mathrm{X}$ (Microcal Origin 6.0, OriginLab Corporation, Northampton, MA, USA). The correlation (R value) and statistical significance ( $p$ value) was indicated after linear fitting.
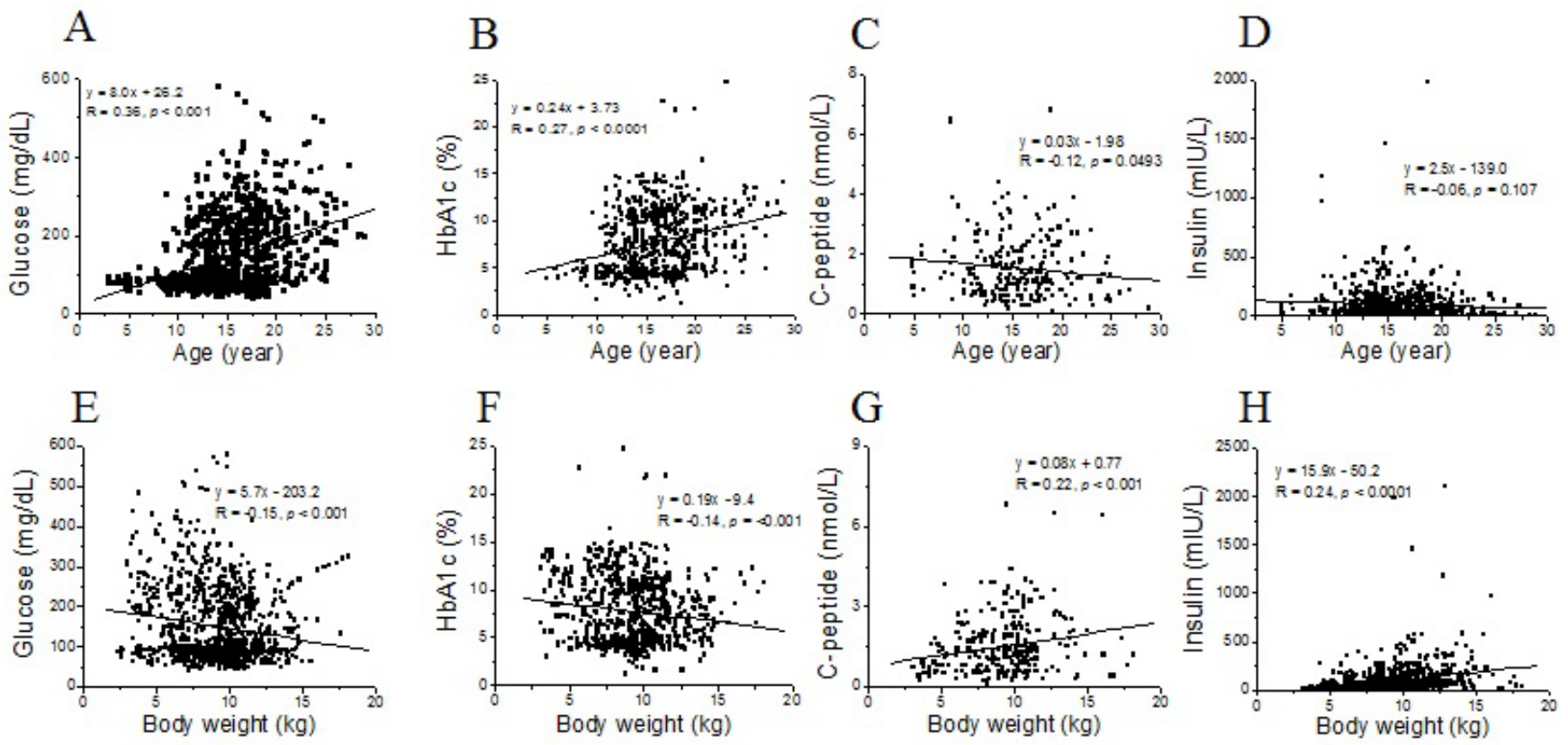

Figure 2: Correlations between age and serum glucose $(A, n=865, p<0.01)$, HbA1c $(B, n=526, p<0.0001), C-p e p t i d e ~(C, n=188, p<0.05)$ and insulin $(D, \mathrm{n}=613, p>0.05)$. Correlations between body weight and serum glucose $(E, \mathrm{n}=878, p<0.01)$, HbA1c $(F, \mathrm{n}=572, p<0.001)$, insulin $(F, \mathrm{n}=646, p<0.0001)$, C-peptide $(G, \mathrm{n}=230, p<0.001)$ and insulin $(H, \mathrm{n}=646, p<0.0001)$. 
The correlations between serum glucose levels and urine several parameters were also analyzed (Table 2). Interestingly, the serum glucose levels in the NHPs correlated well with the urine volumes $(p<0.05)$ and glucose amounts $(p<0.001)$ collected in $24 \mathrm{hrs}$. However, the correlations between serum glucose levels and the amounts of urine albumin, total proteins, creatinine or albumin/ creatinine ratio were not statistically significant ( $p>0.05$, Table 2). These results indicate that higher blood glucose levels could lead to increase in urine volume and glucose execration, but might not represent seriousness levels of diabetic nephropathy.

Table 3: Urine parameters in normoglycemia and hyperglycemia NHPs.

\begin{tabular}{lcc}
\hline \multirow{2}{*}{ Parameter } & Normoglycemia & Hyperglycemia \\
\cline { 2 - 3 }$(\mathbf{n}=\mathbf{2 1}, \mathrm{F} / \mathrm{M}=\mathbf{0} / \mathbf{2 1})$ & $(\mathrm{n}=\mathbf{7 9}, \mathrm{F} / \mathrm{M}=\mathbf{2 4 / 5 5})$ \\
\hline Age (year) & $13.3 \pm 0.5$ & $17.3 \pm 0.5^{* * * *}$ \\
\hline Body weight $(\mathrm{kg})$ & $10.8 \pm 0.4$ & $8.1 \pm 0.3^{* * * *}$ \\
\hline Serum glucose $(\mathrm{mg} / \mathrm{dL})$ & $66.9 \pm 1.8$ & $240.1 \pm 13.4^{* * * *}$ \\
\hline Blood HbA1c $(\%)$ & $5.2 \pm 0.7$ & $9.7 \pm 0.4^{* *}$ \\
\hline Serum ALT (U/L) & $41.3 \pm 7.7$ & $139.5 \pm 21.6^{* * *}$ \\
\hline Serum AST (U/L) & $34.1 \pm 2.5$ & $42.1 \pm 3.9$ \\
\hline Urine assay & & \\
\hline Volume (mL/24 hrs) & $340 \pm 41$ & $583 \pm 43^{* * *}$ \\
\hline Albumin (mg/24 hrs) & $4.9 \pm 1.1$ & $69.8 \pm 13.9^{* * * *}$ \\
\hline Total proteins (mg/24 hrs) & $21.1 \pm 3.0$ & $140.8 \pm 26.7^{* * * *}$ \\
\hline Creatinine (mmol/24h) & $2.0 \pm 0.2$ & $916.2 \pm 289.1^{* * * *}$ \\
\hline Albumin/Creatinine ratio & $2.7 \pm 0.6$ & $56.2 \pm 9.7^{* * *}$ \\
\hline Note: Values arepres
\end{tabular}

Note: Values are presented as Mean \pm SE. $n$ : number of animals; F/M: Female/Male; ${ }^{*}: p<0.05 ;{ }^{* *}: p<0.01 ;{ }^{* * *}: p<0.001 ;{ }^{* * * *}: p<0.0001$; versus Normoglycemia.
The kidney functions were further compared between normoglycemia ( $<85 \mathrm{mg} / \mathrm{dL}$ ) and hyperglycemia $(\geq 85 \mathrm{mg} /$ dL) NHPs (Table 3). Compared with the normal monkeys, the hyperglycemic animals showed significant less body weight, older, high serum glucose, high HbA1c and ALT. Urine assays showed significant increase in $24 \mathrm{hrs}$ urine volume, albumin, total proteins, creatinine and albumin/creatinine ration $(p<0.001$, Table 3$)$. These results demonstrate that diabetes occurs more in aged NHPs and may susceptibly affect liver function. In the meantime, liver and renal functions were impaired in diabetic animals.

\section{General progression and individual cases of spontaneous diabetes in NHPs}

The progression of diabetes can vary among human patients and also in diseased NHPs. To show the general characteristics of diabetic progression in NHPs, Figure 3 summarized the changes of body weight, HbA1c, glucose, insulin and lipids in our housed diabetic NHPs. The average body weight decreased gradually following the ages when the diabetic animals were getting old (Figure 3A). Along with the decrease in body weight, serum insulin level also decreased progressively when the animals got older (Figure 3B). In contrast, blood $\mathrm{HbA1c}$ and serum glucose levels gradually increased during the aging process (Figures $3 \mathrm{~A}$ and 3B). Blood TG and TC kept on staying at high levels with some obvious variabilities during the disease process (Figure $3 \mathrm{C}$ ). The average blood LDL levels in the diabetic NHPs had some moderate increase during the early ages and then increased markedly at their late ages (Figure 3D). However, the blood HDL levels were in a normal range with much less variations during the disease process (Figure 3D). It is interesting that the diabetic monkeys with ages

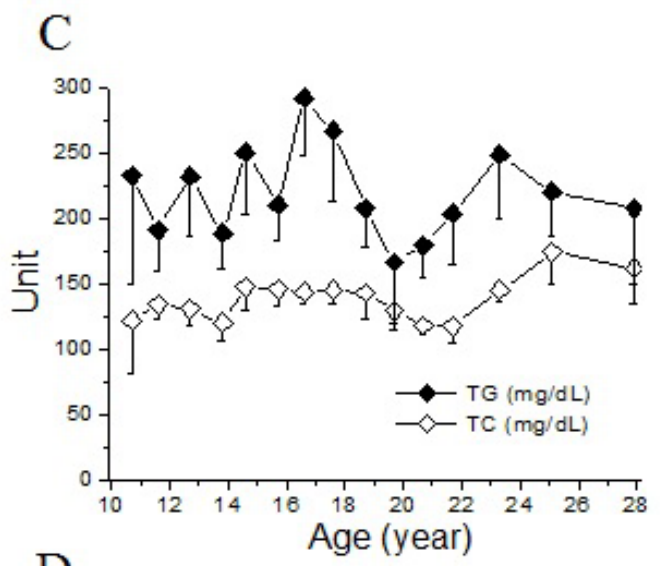

$\mathrm{D}$

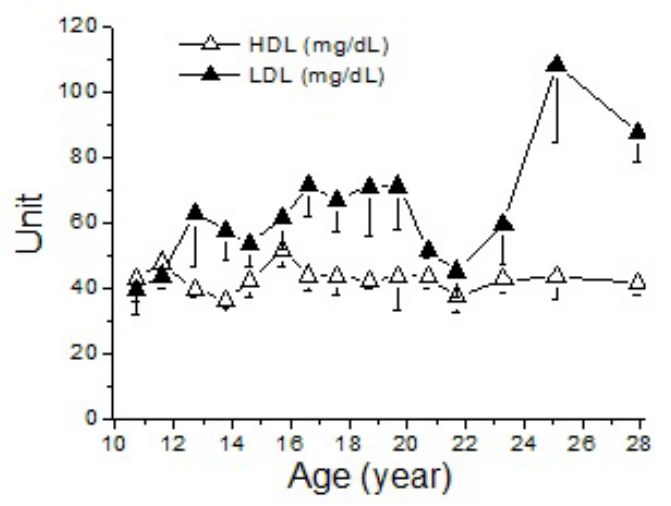

Figure 3: Progressive changes of body weight $(\mathrm{O})$ and HbA1c $(\mathbf{\bullet})$ shown in panel $\boldsymbol{A}$, glucose $(\square)$ and insulin $(\boldsymbol{\square})$ in panel $\boldsymbol{B}$, TG $(\bullet)$ and TC $(\diamond)$ in panel $\boldsymbol{C}$, and HDL $(\triangle)$ and LDL $(\boldsymbol{\Delta})$ in panel $\boldsymbol{D}$ in diabetic NHPs aged from 10 to 28 years. Each data point shows the mean of the results collected from various diabetic animals ( $\mathrm{n}=5$ to 28$)$. 
over 24 years old were found to be female only in this study. Such phenomenon is similar to in humans that women have a longer lifespan than men [38].

To further depict the variations of progressive hyperglycemia in NHPs, the changes of body weight, serum glucose, HbA1c and insulin were presented from the selective individual monkeys with normoglycemia (monkey B07, identification \#), mild hyperglycemia (approximately $100 \mathrm{mg} / \mathrm{dL}, \mathrm{O} 07$ ), and severe hyperglycemia (250 $\mathrm{mg} / \mathrm{dL}, \mathrm{U04}$ ) during past 5 to 10 years after they were housed in our animal facility. The normoglycemic one (B07) was healthy during past over 5 years (from age 13 to nearly 19 years old) with a moderate increase in body weight and minor changes in serum glucose, insulin and HbA1c levels (Figure 4, left panel). The moderate hyperglycemic animal (O07) showed stable body weight and blood $\mathrm{HbA} 1 \mathrm{c}$ during the past 10 years (from age 14 to 24 years old) with a minor increase in serum glucose and insulin (decreased lately) levels (Figure 4, middle panel). The more severe hyperglycemic animal (U04, female) showed stable body weight, serum glucose and $\mathrm{HbA} 1 \mathrm{c}$ during the past 5 years (ages from 11 to 15.6 years old) with a minor decrease in serum insulin (Figure 4 , left panel). These results indicate that not only normal healthy monkeys, but also moderate and severe hyperglycemic animals could survive in our animal facility for many years (5-10 or longer) without dramatic changes on their diabetic conditions.

In contrast, some monkeys showed progressively changes in their diabetic conditions. The serum glucose level and HbA1c of animal O01 were approximately $100 \mathrm{mg} / \mathrm{dL}$ and $5 \%$, respectively, at ages before 19 years old (Figure 5). The serum glucose levels gradually increased to nearly $500 \mathrm{mg} / \mathrm{dL}$ and $\mathrm{HbA} 1 \mathrm{c}$ raised to $11 \%$ or higher at age 24 . In the meantime, body weight and serum insulin were decreased by more than $20 \%$ (Figure 5, O01). The progressive increases in serum glucose and $\mathrm{HbA} 1 \mathrm{c}$ with the decreases in insulin and body weight were observed in monkey L09 during his ages of 14-19 years old (Figure 5, L09). Animal B09 showed
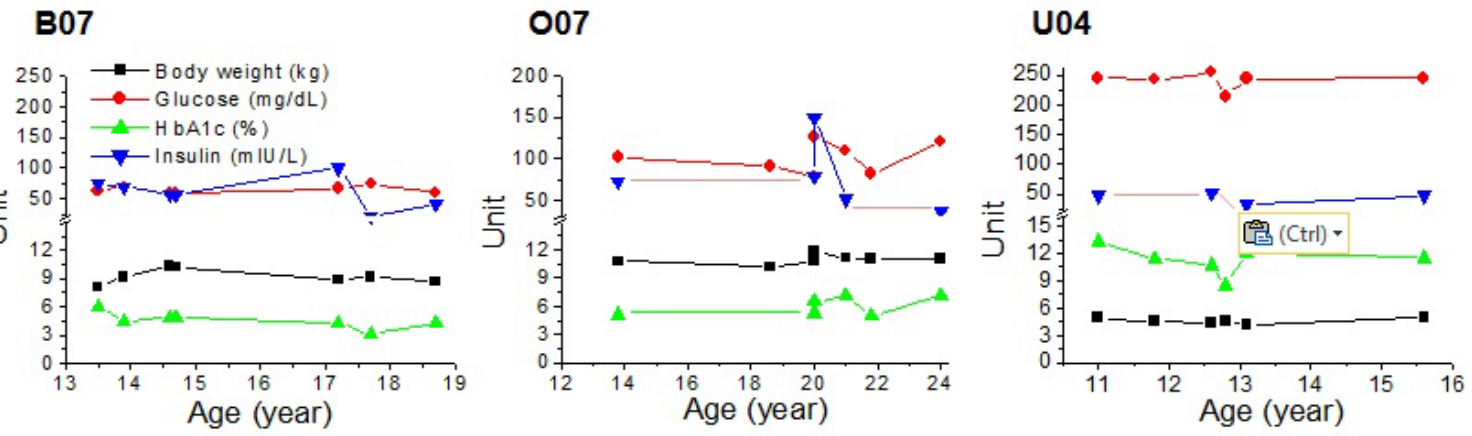

Figure 4: Changes of body weight $(\boldsymbol{\square})$, serum glucose $(\boldsymbol{\bullet})$, blood HbA1c $(\boldsymbol{\Delta})$ and serum insulin $(\boldsymbol{\nabla})$ in individual monkeys following the time course after they were housed in our animal facility. Normoglycemia (monkey ID-B07) and hyperglycemia (moderate, ID-O07 and severe, ID-U04) were selected for the representative individuals to show their progressive changes following their ages from 11 to 24 years old.
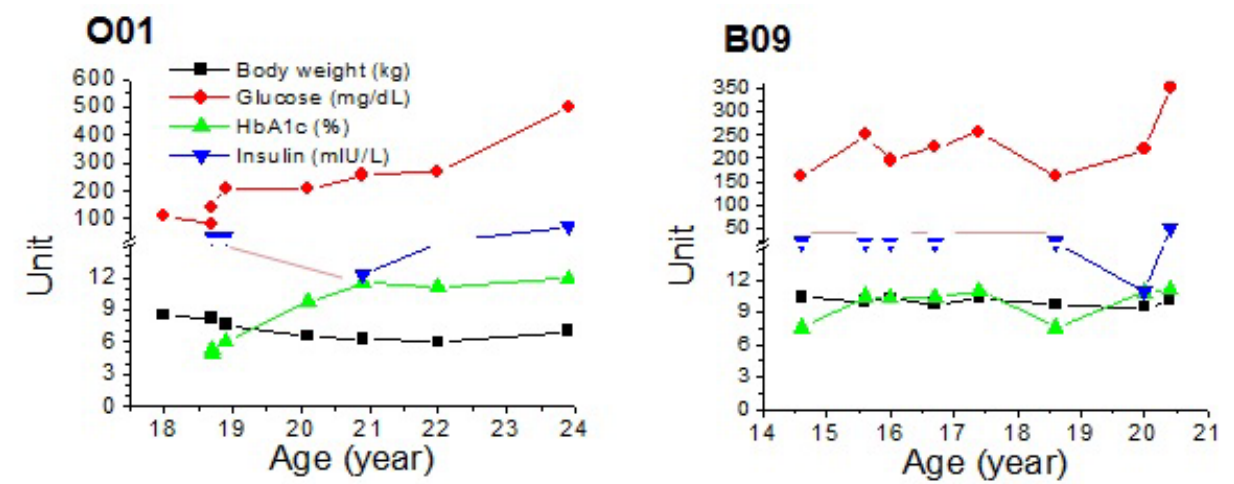

\section{L09}

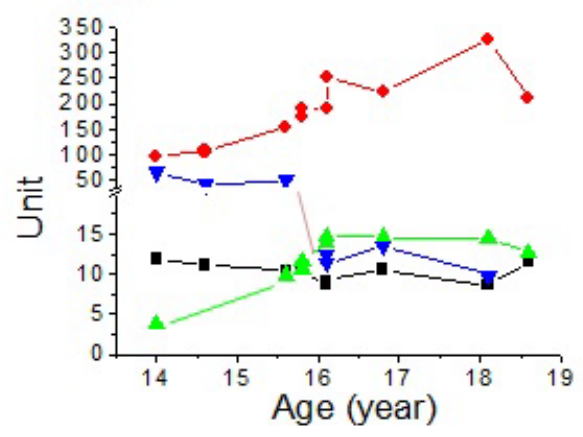

\section{B05}

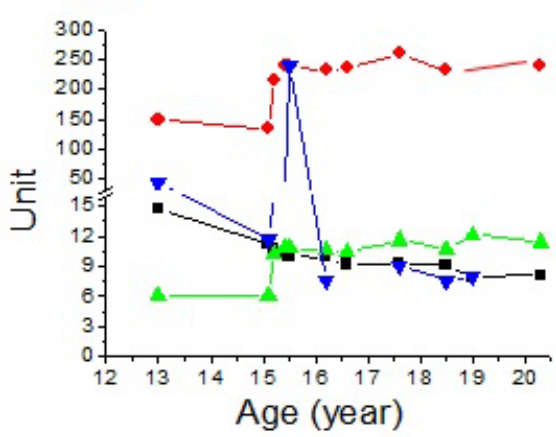

Figure 5: Progressive changes of body weight $(\boldsymbol{\nabla})$, serum glucose $(\boldsymbol{\bullet})$, blood HbA1c $(\boldsymbol{\Delta})$ and serum insulin $(\boldsymbol{\nabla})$ in individual diabetic monkeys following the time course after they were housed in our animal facility. Representative monkeys (ID-O01, L09, B09 and B05) during their ages from 13 to 24 years old showed progressively worsening on their serum glucose and insulin levels, as well as blood HbA1c. In addition, their body weights continuously decreased when their serum glucose levels progressively arised. 
a slow increase in serum glucose level, but remained relatively stable body weight, insulin and HbA1c during past 6 years in our animal facility (Figure 5, B09). However, monkey B05 showed hyperglycemia at age 13 with high insulin, overweight $(15 \mathrm{~kg})$ and mild HbA1c (6\%). Starting from age 15, the animal showed dramatic increases in serum glucose and $\mathrm{HbA} 1 \mathrm{c}$ with a big increase in insulin with markedly reduction of body weight. After age 16, serum glucose and $\mathrm{HbA1c}$ remained at high levels, but insulin decreased to a new low level. Body weight continuously decreased by a total of nearly $50 \%$ during the past 7 years (from 13 to 20 years old, Figure 5, B05). Our data demonstrate that progressions of diabetes in individual monkeys vary, which is similar to in humans as individual patients need to be treated specifically according to patients' various conditions.

In order to learn the correlation between diabetes and dyslipidemia, changes of body weight, serum glucose, insulin, HbA1c, TG, TC, HDL and LDL in diabetic animals were collected and analyzed. Monkey Q07 (Figure 6, left panels) showed the increase in serum glucose levels $(\bullet)$ accompanied with increases in TG $(\boldsymbol{\square})$, LDL $(\diamond)$ and $\operatorname{HbA1c}(\square)$, and with some decrease in $\operatorname{HDL}(\nabla)$ and no much changes on TC $(\boldsymbol{\Delta})$, body weight $(O)$ and insulin $(\triangle)$. The similar manifestations of diabetic progression were observed in monkey R07 during past 5 years (Figure 6, right panels). Serum glucose
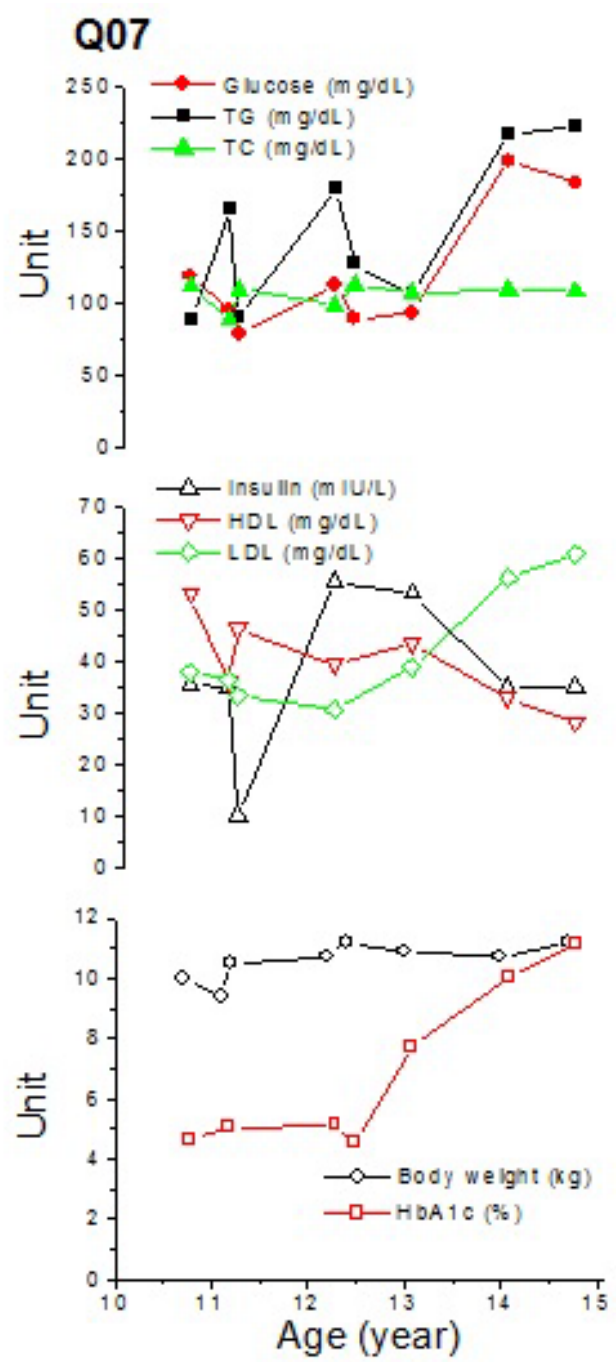

progressively increased accompanied with correspondingly arising in TG $(\square)$, LDL $(\diamond)$ and HbA1c $(\square)$. However, body weight $(\mathrm{O})$, insulin $(\triangle)$ and $\operatorname{HDL}(\nabla)$ were correspondingly reduced with minor changes on TC $(\boldsymbol{A})$. Our data indicate that diabetic procession in NHPs accompanies with dyslipidemia and body weigh changes, which could be similar to the clinical progression in diabetic patients even though our diabetic monkeys enrolled in this study were not with antidiabetic therapy. Therefore, NHPs could be reliably used in preclinical studies as NHPs show high similarities to human genomics, physiology and disease process [39-42]. Evidently, the results derived from NHP studies have paralleled the results of later studies performed in humans $[43,44]$, which reinforces the utility of NHPs as an excellent preclinical animal model for investigating the physiology of human metabolism and the pathophysiology of metabolic dysfunction.

\section{STREPTOZOCIN-INDUCED DIABETES IN NHPS}

Drug-induced hyperglycemia in NHPs is also broadly used in diabetic research, especially for islet or beta cell transplantation. Streptozocin (STZ), a naturally occurring glucosamine-nitrosourea compound, has been used for diabetogenic induction in NHPs due to its high toxicity to pancreatic beta cells [45]. The diabetogenic effects of STZ by multiple low doses or by single high dose in

\section{R07}
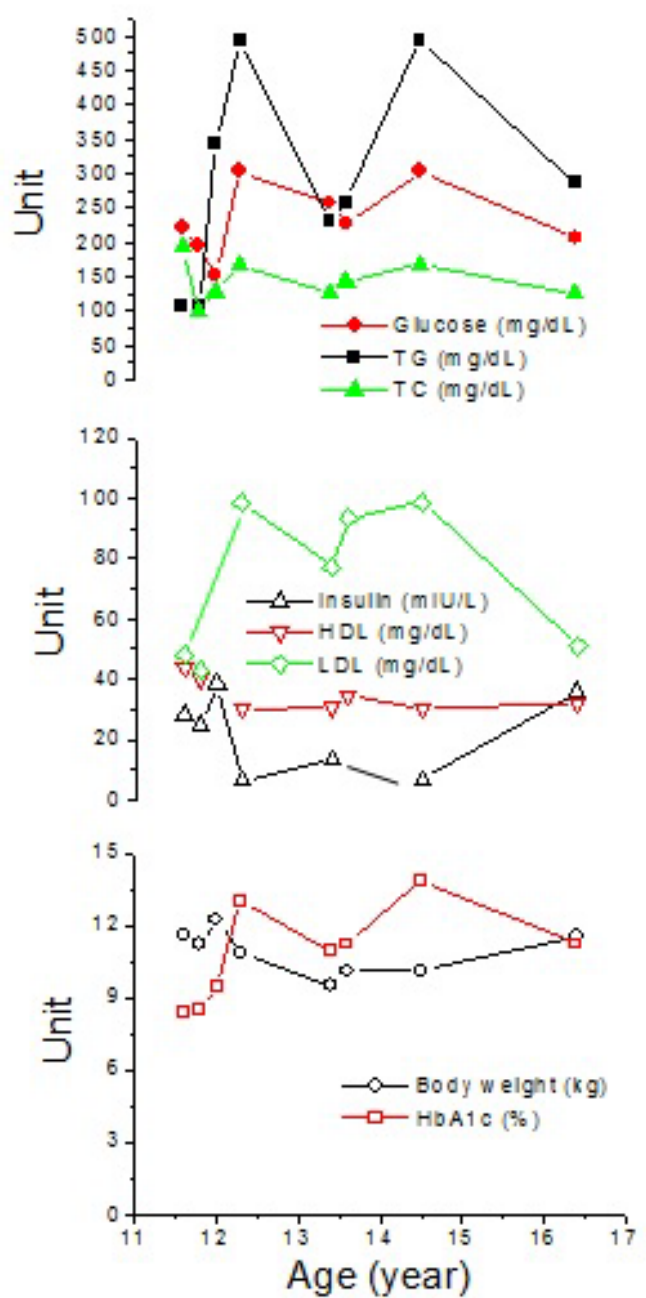

Figure 6: Selected individual diabetic monkeys represented the correlated changes of body weight $(\bigcirc)$, serum glucose $(\mathbf{O})$, blood HbA1c $(\square)$ and serum insulin $(\triangle)$ with serum lipids of TG $(\boldsymbol{\square})$, TC $(\boldsymbol{\Delta})$, HDL $(\nabla)$ and LDL $(\diamond)$ during the time being housed in our animal facility. Monkey Q07 and R07 showed progressively increases in glucose, HbA1c, TG and LDL. However, their HDLs decreased and R07 body weight and insulin also reduced. 
A

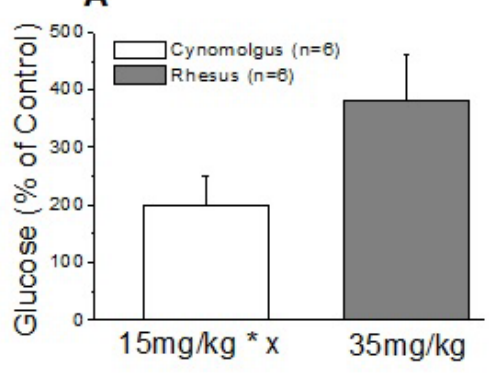

C

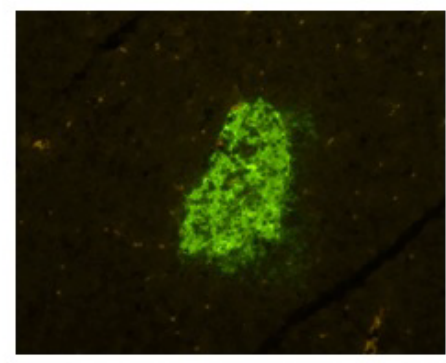

B

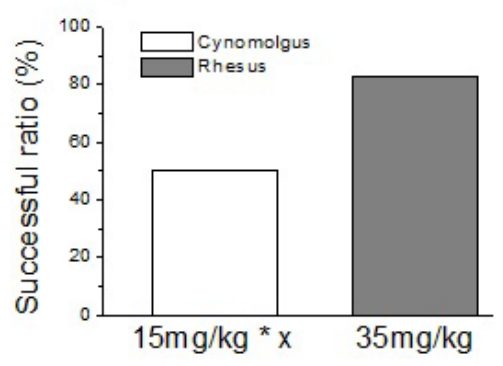

D

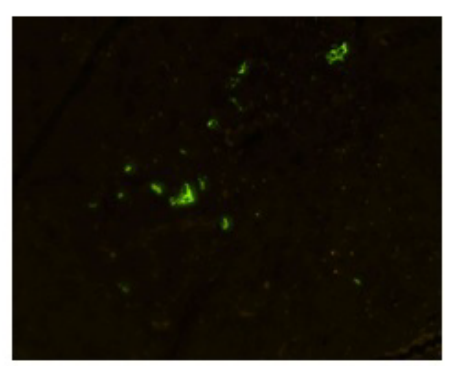

Figure 7: Successful induction of hyperglycemia with multiple low doses $\left(15 \mathrm{mg} / \mathrm{kg}^{*} \mathrm{x}\right)$ or single high dose $(35 \mathrm{mg} / \mathrm{kg})$ of STZ in cynomolgus or rhesus monkeys. Each monkey in cynomolgus group $(\mathrm{n}=6)$ was intravenously administered with multiple doses of $15 \mathrm{mg} / \mathrm{kg}$ STZ once every 2 to 4 weeks until successful induction of hyperglycemia or until the end of study. Each monkey in rhesus group was intravenously injected with $35 \mathrm{mg} / \mathrm{kg}$ STZ once. Increase in serum glucose $(\%$, panel $\boldsymbol{A})$ and the successful ratio of hyperglycemia is shown in panel $\boldsymbol{B}$. Immunohistochemical staining against insulin in islets observed from paraffin-sectioned pancreatic slides (20x) in the monkeys with normoglycemia ( $\boldsymbol{C}$, green area) and with hyperglycemia by $>300 \mathrm{mg} /$ $\mathrm{dL}$ constantly $(\boldsymbol{D}$, scattered green areas) after STZ treatment.

normoglycemic NHPs were investigated [46]. Each monkey in the $1^{\text {st }}$ group $(n=6)$ was intravenously administered with 7.5 to 15 $\mathrm{mg} / \mathrm{kg}$ STZ once every 2 to 4 weeks until successful induction of hyperglycemia or until the end of this 28 -week study. In the $2^{\text {nd }}$ group $(n=7)$ each monkey was intravenously injected with $35 \mathrm{mg} /$ $\mathrm{kg}$ STZ once only. Compared with STZ multiple low doses, single high dose caused much severe insulin depletion, similar to Type I diabetes. Among them one animal died on the $2^{\text {nd }}$ day after STZ high dose [46]. Beta-cell sensitivity to STZ toxicity varied obviously among individual monkeys, some highly sensitive and some almost no response. Therefore, extra caution may need to be taken to avoid incidental death if single high dose is administered. The successful rate of diabetogenic effects was approximately $50 \%$ with multiple low doses of $15 \mathrm{mg} / \mathrm{kg}$ and $83 \%$ after one high single dose $35 \mathrm{mg} /$ $\mathrm{kg}$ with great loss of beta cells in islets (Figure 7). Litwak et al. found $30 \mathrm{mg} / \mathrm{kg}$ STZ did not reliably cause diabetes and only 35\% became mildly hyperglycemic in cynomolgus monkeys [47]. Fifty $\mathrm{mg} / \mathrm{kg}$ STZ reached $80 \%$ hyperglycemia in treated cynomolgus monkeys [48]. Using $55 \mathrm{mg} / \mathrm{kg} \mathrm{STZ} \mathrm{induced} \mathrm{100 \%} \mathrm{diabetogenic} \mathrm{effects} \mathrm{for}$ up to 1 year without any evidence of regeneration of the beta-cells in cynomolgus monkeys [49]. The diabetogenic effects of STZ were also examined in rhesus monkeys and found $71 \%$ animals treated with $45 \mathrm{mg} / \mathrm{kg}$ and $100 \%$ animals received $60 \mathrm{mg} / \mathrm{kg}$ developed hyperglycemia [50]. These results indicate that nonhuman primates show their various responses to STZ diabetogenic induction.

The underline mechanism of such obvious variability in NHPs responded to STZ is not fully delineated. Diabetogenic dose of STZ may relate to the animal age, body weight, route of administration, and nutritional status [51-53]. In addition, the individual genetic, health and physiological differences, such as receptor expression levels, may also contribute to the wide variance in STZ doses among experimental animals. Another possibility of these discrepancies could be beta-cells in some monkeys are more resistant to STZ toxic effect. For example, insulin producing cells that do not express
GLUT2 (glucose transporter 2) in the plasma membrane are resistant to STZ toxicity and only become vulnerable to STZ toxicity after expression of GLUT2 protein in the plasma membrane [54]. Therefore, to successfully establish STZ-induced diabetic model in NHPs, an optimal dose or feasible approach is necessary. Such dose or approach can induce irreversible and stable diabetes (more similar to T2DM) with much less adverse effects. Our data provide some insights on the model induction in NHPs, because approximately $50 \%$ monkeys treated with multiple low doses of STZ were hyperglycemic without any observable side effects and with no need of exogenous insulin therapy (Figure 7). Our data demonstrate that single high dose of STZ resulted in more severe diabetogenic effects (similar to type I) than multiple low doses (similar to Type II). Single high dose of STZ was accompanied more serious side effects, including insulin dependence, liver damage, kidney impairment and animal death. These results may help researchers to understand the diabetogenic process and variability of STZ induction in NHPs and to choose a severe or moderate hyperglycemic model for their research need.

\section{ADVANTAGES AND LIMITATIONS WITH USING NHPS IN RESEARCH}

More monkeys are enrolled in biomedical research in recent years and reached a record number according to one 2018 report [55]. Significant advantages of NHP models for drug and new therapy development include their close genetic identity and physiological similarity to humans, especially in studies involving recombinant biologics targeting human receptors or proteins. Another advantage of studies in NHPs compared with in humans is that diet and pharmacological interventions can be well controlled, whereas compliance with dietary and drug treatment regimens is generally quite poor in free-living human subjects. In fact, in dietary studies in NHPs, compliance with the dietary regimen can be known 
with near certainty. Compared with extremely strict limitations in humans, biopsies of a variety of tissues including adipose, muscle, liver and kidney can be performed in NHP studies, particularly with minimally invasive approaches (e.g., echography-guided or laparoscopic biopsy). In addition, tissues samples, such as central neuronal tissues from critical areas or from other life-organs, cannot be obtained in humans, but can be collected at the time of necropsy in NHP studies designated to have a terminal endpoint. Furthermore, compared with rodents or other small animals, relatively large blood volume possibly being sampled in NHPs is also critical for some studies which require frequent bleedings with enough amount for multiple assays.

The main disadvantages of using NHPs versus other animal models can be the limited resources of animals and high expenses for maintaining colonies and performing experiments. Of course, compared with similar clinical trials, NHP studies are far less expensive [56]. However, NHP studies still can lead to greater and more rapid advances in the evaluation and translation of novel therapies. In addition, specific facilities and technical expertise are extremely important for running successful NHP studies.

\section{CONCLUSION}

The global prevalence of diabetes requires extensive investigation on understanding its mechanism and developing new therapy, which can be markedly tardy by lack of critical animal models. In this article the diabetic models of NHPs are introduced and characteristic data are presented. The general metabolic manifestation of the monkeys with naturally occurring diabetes was significantly older, compared with non-diabetic ones. Their ages correlated well with their blood glucose and HbA1c levels, but did not correlate well with blood insulin levels. In addition, their body weights correlated well with their blood levels of glucose, HbA1c, insulin and C-peptide. Our data also show the progression of diabetes in the NHPs during past 5 to 10 years. The results of ivGTT and oGTT demonstrate the development of insulin resistance in diabetic NHPs. Although none of preclinical models can completely capture the complexity of human dysmetabolic syndrome, the naturally occurring diabetes in NHPs is most likely the closest preclinical model to human diabetes, such as loss of blood glucose control, complications and dyslipidemia.

\section{DECLARATIONS}

\section{Research involving human participants and/or animals}

This study did not involve humans, but was conducted in monkeys. The study protocol and experimental procedures used in this study were approved by the IACUC of Crown Bioscience Inc., which includes member from outside of the company. The approval numbers are AN-1308-016-19 and AN-1507-004.

\section{Conflict of interests}

The authors are employee of Crown Bioscience Inc. The authors declare no conflict of interest in this study.

\section{Informed consent}

The authors have read and approved the manuscript for submission.
Their consents are available if requested.

\section{Availability of data and material}

All the materials and relevant raw data supporting our findings can be found in Tables and Figures in the manuscript and are freely available to readers or scientists wishing to use them for noncommercial purposes.

\section{Funding}

This study was supported by the internal research fund from Crown Bioscience, Inc.

\section{Authors' contributions}

Y-F Xiao and Y (Jim) Wang participated in study design, data collection and analysis, as well as figure and manuscript preparation.

\section{Acknowledgements}

We are very grateful to our department employees who participated the experiments and data collections and also to our animal center employees for their professional care of the animals and excellent technical assistances during the study.

\section{REFERENCES}

1. Muoio DM, Newgard CB. Mechanisms of disease:Molecular and metabolic mechanisms of insulin resistance and beta-cell failure in type 2 diabetes. Nat Rev Mol Cell Biol. 2008;9:193-205.

2. Forbes JM, Cooper ME. Mechanisms of diabetic complications. Physiol Rev. 2013;93:137-188.

3. Shaw JE, Sicree RA, Zimmet PZ. Global estimates of the prevalence of diabetes for 2010 and 2030. Diabetes Res Clin Pract. 2010;87:4-14.

4. Xie M, Ye H, Wang H, Charpin-El Hamri G, Lormeau C. $\beta$-cellmimetic designer cells provide closed-loop glycemic control. Science. 2016;354:1296-1301.

5. Falkevall A, Mehlem A, Palombo I, Heller Sahlgren B, Ebarasi L. Reducing VEGF-B Signaling Ameliorates Renal Lipotoxicity and Protects against Diabetic Kidney Disease. Cell Metab. 2017;25:713-726.

6. King AJ. The use of animal models in diabetes research. Br J Pharmacol. 2012;166:877-894.

7. Sasase T, Pezzolesi MG, Yokoi N, Yamada T, Matsumoto K. Animal models of diabetes and metabolic disease. J Diabetes Res. 2013;2013:281928.

8. Chatzigeorgiou A, Halapas A, Kalafatakis K, Kamper E. The use of animal models in the study of diabetes mellitus. In Vivo. 2009;23:245 258.

9. Islam MS. Animal models of diabetic neuropathy: progress since 1960 s. J Diabetes Res. 2013;2013:149452

10. Wang X, Wang B, Sun G, Wu J, Liu Y, Wang Y, et al. Dysglycemia and Dyslipidemia Models in Nonhuman Primates: Part I. Model of Naturally Occurring Diabetes. J Diabetes Metab. 2015;S13:010.

11. Wang B, Sun G, Liu Y, Qiao J, Ye W, Wang H, et al. Dysglycemia and Dyslipidemia Models in Nonhuman Primates: Part II. Model of Naturally Occurring or Experimental Obesity. J Diabetes Metab. 2016;6:641.

12.Wagner JD, Cline JM, Shadoan MK, Bullock BC, Rankin SE, Cefalu WT. Naturally occurring and experimental diabetes in cynomolgus monkeys: a comparison of carbohydrate and lipid metabolism and islet pathology. Toxicol Pathol. 2001;29:142-148. 
13. Harwood HJ, Listrani P, Wagner JD. Nonhuman primates and other animal models in diabetes research. J Diabetes Sci Technol. 2012;6:503. 514 .

14. Wagner JD, Kavanagh K, Ward GM, Auerbach BJ, Harwood HJ Jr, Kaplan JR. Old World Nonhuman Primate Models of Type 2 Diabetes Mellitus. ILAR J. 2006;47:259-271.

15.Zhu H, Yu L, He Y, Wang B. Nonhuman primate models of type 1 diabetes mellitus for islet transplantation. J Diabetes Res 2014;2014:785948.

16. Scicchitano, P, Cameli M, Maiello M, Modesti PA, Muiesan ML, Novo S, et al. Nutraceuticals and dyslipidaemia: Beyond the common therapeutics. J Funct Foods. 2014;6:11-32.

17. Wagner JD, Kavanagh K, Ward GM, Auerbach BJ, Harwood HJ Jr, Kaplan JR. Old World Nonhuman Primate Models of Type 2 Diabetes Mellitus. ILAR J. 2006;47:259-271.

18.Zhu H, Yu L, He Y, Wang B. Nonhuman primate models of type 1 diabetes mellitus for islet transplantation. J Diabetes Res. 2014;2014:785948.

19. Brissova M, Fowler MJ, Nicholson WE, Chu A, Hirshberg B, Harlan $\mathrm{DM}$, et al. Assessment of human pancreatic islet architecture and composition by laser scanning confocal microscopy. J Histochem Cytochem. 2005;53:1087-1097.

20.Cabrera O, Berman DM, Kenyon NS, Ricordi C, Berggren PO, Caicedo A. The unique cytoarchitecture of human pancreatic islets has implications for islet cell function. Proc Natl Acad Sci USA. 2006; 103:2334-2339.

21. Bosco D, Armanet M, Morel P, Niclauss N, Sgroi A, Muller YD, et al. Unique arrangement of alpha- and beta-cells in human islets of Langerhans. Diabetes. 2010;59:1202-1210.

22.Zou C, Wang J, Wang S, Huang F, Ren Z, Chen Z, et al. Characterizing the induction of diabetes in juvenile cynomolgus monkeys with different doses of streptozotocin. Sci China Life Sci. 2012;55:210-218.

23.Pitkin RM, Reynolds WA. Diabetogenic effects of streptozotocin in rhesus monkeys. Diabetes. 1970;19:85-90.

24.Litwak KN, Cefalu WT, Wagner JD. Streptozotocin-induced diabetes mellitus in cynomolgus monkeys: changes in carbohydrate metabolism, skin glycation, and pancreatic islets. Lab Anim Sci. 1998;48:172-178.

25.Thomas JM, Contreras JL, Smyth CA, Lobashevsky A, Jenkins S, Hubbard WJ, et al. Successful reversal of streptozotocin-induced diabetes with stable allogeneic islet function in a preclinical model of type 1 diabetes. Diabetes 2001;50:1227-1236.

26. Kavanagh K, Flynn DM, Nelson C, Zhang L, WagnerJD. Characterization and validation of a streptozotocin-induced diabetes model in the vervet monkey. J Pharmacol Toxicol Methods. 2011;63:296-303.

27. Contreras JL, Smyth CA, Curiel DT, Eckhoff DE. Nonhuman primate models in type 1 diabetes research. ILAR J. 2004;45:334-342.

28.Xiao YF, Wang B, Wang X, Du F, Benzinou M, Wang YX. Xylazineinduced reduction of tissue sensitivity to insulin leads to acute hyperglycemia in diabetic and normoglycemic monkeys. BMC Anesthesiol. 2013;13:33.

29.Guo S, Qian W, Du F, Wang B, Wang X, Fang Y, et al. Proteinuria in Cynomolgus macaques (Macaca fascicularis) with Spontaneously Developed Metabolic Disorder and Diabetes: Transcriptome Analysis of Biopsy Kidney. J Diabet Metab. 2014;5:334.

30.Wang X, Hansen BC, Shi D, Fang Y, Du F, Wang B, et al. Quantification of beta-cell insulin secretory function using a graded glucose infusion with C-peptide deconvolution in dysmetabolic, and diabetic cynomolgus monkeys. Diabetol Metab Syndr. 2013;5:40

31. Hansen BC, Bodkin NL. Heterogeneity of insulin responses: phases leading to type 2 (non-insulin-dependent) diabetes mellitus in the rhesus monkey. Diabetologia. 1986;29:713-719.

32.Bodkin NL, Ortmeyer HK, Hansen BC. Diversity of insulin resistance in monkeys with normal glucose tolerance. Obes Res. 1993;1:364-370.

33. Bodkin NL, Hannah JS, Ortmeyer HK, Hansen BC. Central obesity in rhesus monkeys: association with hyperinsulinemia, insulin resistance and hypertriglyceridemia? Int J Obes Relat Metab Disord. 1993;17:5361.

34.Hansen BC, Bodkin NL. Primary prevention of diabetes mellitus by prevention of obesity in monkeys. Diabetes. 1993;42:1809-1814.

35.Kemnitz JW. Obesity in macaques: spontaneous and induced. Adv Vet Sci Comp Med. 1984;28:81-114.

36. Hansen BC. Investigation and treatment of type 2 diabetes in nonhuman primates. Methods Mol Biol. 2012;933:177-185.

37. Hansen BC, Bodkin NL. Standardization of IVGTT. Importance of method used to calculate glucose disappearance. Diabetes Care. $1993 ; 16: 847$

38.Ginter EVS. Women live longer than men. Bratisl Lek Listy. 2013;114:45-49.

39.Gibbs RA, Rogers J, Katze MG, Bumgarner R, Weinstock GM, Mardis $\mathrm{ER}$, et al. Evolutionary and biomedical insights from the rhesus macaque genome. Science. 2007;316:222-234.

40.Rogers J, Gibbs RA. Comparative primate genomics: emerging patterns of genome content and dynamics. Nat Rev Genet. 2014;15:347-359.

41. Hansen BC, Bodkin NL. Primary prevention of diabetes mellitus by prevention of obesity in monkeys. Diabetes. 1993;42:1809-1814.

42.Bodkin NL, Nicolson M, Ortmeyer HK, Hansen BC. Hyperleptinemia: relationship to adiposity and insulin resistance in the spontaneously obese rhesus monkey. Horm Metab Res. 1996;28:674-678.

43.Ahrén B, Holst JJ. The cephalic insulin response to meal ingestion in humans is dependent on both cholinergic and noncholinergic mechanisms and is important for postprandial glycemia. Diabetes. 2001;50:1030-1038.

44.Havel PJ, Ahren B. Activation of autonomic nerves and the adrenal medulla contributes to increased glucagon secretion during moderate insulin-induced hypoglycemia in women. Diabetes. 1997;46:801-807.

45.He S, Wang D, Wei L. Practical and critical instruction for nonhuman primate diabetic models. Transplant Proc. 2013;45:1856-1865.

46.Liu Y, Gao J, Wang X, Wang YJ, Xiao YF. Dysglycemia and Dyslipidemia Models in Nonhuman Primates: Part III. Type I or II Diabetogenic Effects of Streptozocin. J Diabet Metab. 2019;10:823

47. Litwak KN, Cefalu WT, Wagner JD. Streptozotocin-induced diabetes mellitus in cynomolgus monkeys. changes in carbohydrate metabolism, skin glycation, and pancreatic islets. Lab Anim Sci. 1998;48:172-178.

48.Stegall MD, Chabot J, Weber C, Reemtsma K, Hardy MA. Pancreatic islet transplantation in cynomolgus monkeys. Initial studies and evidence that cyclosporine impairs glucose tolerance in normal monkeys. Transplantation. 1989;48:944-950.

49.Koulmanda M, Oipoa A, Chebrolua S, O'Neilb J, Auchincloss H Jr, Smith RN. The Effect of Low Versus High Dose of Streptozotocin in Cynomolgus Monkeys (Macaca Fascilularis). Am J Transplant. 2003;3:267-272.

50.Pitkin RM, Reynolds WA. Diabetogenic effects of streptozotocin in rhesus monkeys. Diabetes. 1970;19:85-90.

51. Sakata N, Yoshimatsu G, Tsuchiya H, Egawa S, Unno M. Animal 
models of diabetes mellitus for islet transplantation. Exp Diabetes Res. 2012;2012:11.

52.Eleazu CO, Eleazu KC, Chukwuma S, Essien UN. Review of the mechanism of cell death resulting from streptozotocin challenge in experimental animals, its practical use $\mathrm{k}$ to humans. Diabetes Metab Syndr. 2013;12:60.

53.Hayashi K, Kojima R, Ito M. Strain differences in the diabetogenic activity of streptozotocin in mice. Biol Pharm Bull. 2006;29:1110-1119.
54.Elsner M, Guldbakke B, Tiedge M, Munday R, Lenzen S. Relative importance of transport and alkylation for pancreatic beta-cell toxicity of streptozotocin. Diabetolgia. 2007;43:1528-1533.

55.David G. Record number of monkeys being used in U.S. research. Plants \& Animals Scientific Community. 2018.

56.Courtine G, Bunge MB, Fawcett JW. Can experiments in nonhuman primates expedite the translation of treatments for spinal cord injury in humans? Nat Med. 2007;13:561-566. 